\title{
Customer segmentation based on psychographic and demographic aspects as a determinant of customer targeting in the online environment
}

\author{
Elvira Nica ${ }^{1}$, Lubica Gajanova ${ }^{2}$, Eva Kicova ${ }^{2}$ \\ 1 The Center for Human Resources and Labor Studies \\ at AAER and The Bucharest University of Economic Studies \\ 2 University of Žilina
}

\begin{abstract}
Because of the large number of communication tools available in the online environment, besides creating an attractive product, hotel management needs to accurately target each segment through meaningful content and find a relevant communication journey of informational nature. For this reason, the aim of the contribution is to propose customer segmentation based on psychographic and demographic aspects as a determinant of customer targeting in the online environment. Due to the impossibility of its determination and subsequent application across the entire market, we determined the segmentation in the selected industry based on a survey of customers (hotel guests) in the Slovak Republic. By means of scientific research methods such as excerpting, description, comparative analysis, deduction and induction, determination of absolute and relative number, level of mean values, confirmation of the existence of dependency between variables, we extracted the obtained data from marketing research into the required information necessary to fulfill the aim of the contribution.
\end{abstract}

Keywords: customer, segmentation, online environment, hotel industry.

\section{Introduction}

Because of the current global crisis of tourism, many entities seek to analyse the reasons and impacts of the crisis in the tourism and follow-up services. Regardless of the different attributes for bringing the phenomenon of travel to the forefront to as many clients as possible, hotel marketing cannot neglect the appropriateness of distributing information 
(marketing communication). As the primary role of marketing communication is to influence the consumer towards purchasing a product or service, this marketing mix tool is under considerable pressure to achieve demonstrable business results in forms such as influencing the sale of products and services, increasing brand awareness, or getting customer information.

In order to reduce this pressure, hotels are looking for new solutions. It can be stated from the above that marketing communication is a tool of the marketing mix, which is characterized by constantly emerging new trends. With the development of the media, the structure of users and target clients has changed significantly. The enormous boom of the online environment gives multiple opportunities to communicate with target groups. Because of the large number of communication tools available in the online environment, besides creating an attractive product, hotel management needs to accurately target each segment through meaningful content and find a relevant communication journey of informational nature. For this reason, the aim of the contribution is to propose customer segmentation based on psychographic and demographic aspects as a determinant of customer targeting in the online environment. Due to the impossibility of its determination and subsequent application across the entire market, we determined the segmentation in the selected industry based on a survey of customers (hotel guests) in the Slovak Republic.

\section{Literature review}

The marketing communication program can be built on the foundations provided by the communication model, respectively communication process (Clow and Back, 2008). This means that marketing communication involves identifying the target audience and shaping a coordinated communication program to produce the desired response from that audience, as the communication world has become a complicated complex and the changes have made it necessary to add new elements to the basic communication mix.

New forms of marketing communication are associated with the development of technology, online communication, the Internet and social media in the early 21 st century. This means that the new form of marketing communication will be tools and techniques in an online environment that have not been involved in creating and building a strong and mutual relationship between the business and its customers. Pizano (2012) ranks among the new forms of marketing communication: behavioural targeted banner advertising, in-text advertising, social network marketing, online video advertising, location-based marketing, PPC marketing, influencer marketing, online booking systems, email marketing and enterprise web page.

The rise in promotional costs, especially in media, forces businesses to take a very responsible approach to identifying their customers (Krylov, 2019, Chijioke, 2018). This implies that many businesses use the value spectrum model that according to Kramárová (2009) puts the system into marketing communications by determining the most 
effectiveness content and media combination. The whole model consists of the following steps:

- Creating a value spectrum - through which the company quantifies the value of its customers and then determines their importance.

- Extending the value spectrum with a dimension of loyalty - the success of a business is not only guaranteed by the individual value of the customer, but also by the long-term relationship between the business and the customer.

- Setting up a communication campaign for each segments based on the harmonization of communication tools.

At the same time, this model achieves a more efficient budget allocation according to the customer's lasting value (customer profitability determines the distribution of the communication budget between and among customer groups), gains more relevant customer information in each segment. The information mainly concerns the needs of customers, which can then be met in a targeted way, and a meaningful integration of communication tools according to specified tasks in individual segments will achieve a synergistic effect of marketing communication. (Kramárová, 2009). It follows that the effectiveness of marketing communication in the company is determined by the definition of target groups of customers. Socio-demographic variables (age, education, income, occupation and family status) are important factors in which an enterprise can detect its priority target segments. Psychographic segmentation is a response to demographic limitations in the area of behaviour prediction. The construct of the pychographic profile of the segment is based on person's characteristics according to AIO model. The AIO model monitors Activities, Interest and Opinions and combines both external and internal characteristics to map lifestyles. (Queiroz, 2019; Valetteflorence, 1990).

Determination of target groups helps the hotel better plan adequate online communication, i.e. for the hotel it is necessary to create heterogeneous communication messages for heterogeneous groups and to use adequate online communication channels or methods for each identified segment. In the case of the content of the communication report, Maráková (2016) distinguishes the following strategic aspects of its delivery to to customers), emotionally (the content of the report raises positive or negative emotions motivating the purchase of a hotel product) and morally (the content of the report focuses on the recipients' ability to understand what is right). When selecting and creating a communication message, it is necessary to consider not only its content, but also its structure, style and format (Maráková, 2016). The hotel determines the structure by telling the communication message to the identified groups. The best communication messages include those that encourage the identified group to draw its own conclusions about it (Maráková, 2016). The hotel can apply formal or informal, simple, complex or professional style. The hotel determines the format of the communication message depending on the type of communication method (Kotler et al., 2007).

According to Maráková (2016), online communication channels through which the hotel can communicate its message are divided to primary and secondary ones. Primary online 
communication channels are made up of websites, including the hotel website, which constitute the primary source of information about hotel products respectively services. Secondary online communication channels consist of social networks, online advertising, online reservation systems, geolocation services etc. When choosing an online communication channel, the hotel should take into account the following decisive factors: to which online communication channels the target audience pay increased attention, and which online communication channels will highlight the hotel itself. Gúčik (2011) differentiates online communication channels into two groups. The first group consists of interactive online communication channels that provide information created and also verified by the hotel (online videos, hotel website). Their character is primary. These online communication channels are subject to the highest level of control, but with the possibility of a higher risk of distrust of customers. The group of interactive online communication channels is also made up of secondary ones, i.e. channels providing information created and verified by the company with the possibility of open discussion of the company with customers (social networks, interactive websites). The second group consists of personal online communication channels, which may also be primary or secondary in nature, based on the provision of information generated and verified by other people. Primary personal communication channels consist mainly of own experience or providing information directly from hotel staff. Secondary personal communication channels include communication activities related to e-WOM marketing, e-mailing and blogs.

\section{Methods and Data}

The aim of the paper was to propose Customer segmentation based on psychographic and demographic aspects as a determinant of customer targeting in the online environment. Due to the impossibility of its determination and subsequent application across the entire market, we determined the segmentation in the selected industry based on a survey of customers (hotel guests) in the Slovak Republic. With regard to the objective of the paper, the information needs of research were formulated, namely the finding of the level of use (preference) of new forms of online marketing communication by customers in the Slovak Republic and the impact of these forms on their decision in the hotel selection. At the beginning of the research, we looked at its merits within the hotel industry and therefore we set out the research question: Does hotel online marketing communication affect the customer's decision?

To answer this research question, we asked the respondents in a marketing survey focused on customers (hotel guests), whether their communication with the hotel over the Internet suits them, whether they consider the hotel providing its information over the Internet to be better, and to what extent the respondents agree the fact that the internet communication of the hotel influenced them in its choice. The obtained data were statistically tested using hypotheses: 
- Hypothesis A: $80 \%$ of customers in the Slovak Republic are satisfied with communication with the hotel via the Internet.

- Hypothesis B: $80 \%$ of customers in the Slovak Republic think that marketing communication with the hotel via the Internet is more efficient than traditional communication tools.

- Hypothesis C:80\% of customers in the Slovak Republic agree that the new forms of online marketing communication used by hotels have an impact on their decision to choose this hotel.

- Hypothesis D: $80 \%$ of customers in the Slovak Republic consider a hotel that provides its information through the new forms of online marketing communication used to be of higher quality.

For customer-oriented hypotheses, we used statistical one tailed test with alpha level 0.05 .

We assume that the research question will be evaluated positively, as online marketing communications in the hotel industry play an increasingly important role in shaping customer attitudes and evaluating online communication activities (Brettel a SpillerAtting, 2013). The area of online marketing communications is becoming important for hotels due to a significant change in the characteristics of the hotel industry clientele. The post-crisis period brings to the scene a traveler who is aware of his values as well as the value of services offered to him through hotels (Jakovic, Galetic, 2014). While previously hoteliers have been more focused on the physical product itself, they are now more focused on guaranteeing the stability and clear image of their brand, transparent prices, and attracting clients, particularly with regard to re-interest through various forms of online marketing communications that different hotel from the rest of the competition (Järvinen et al., 2012). The effectiveness of marketing communication in the company is determined by the definition of target groups of customers.

Demographic criteria are most obvious to marketing and are quite easy to obtain compared to other ones. If these characteristics of customer change over time, it can be assumed that their consumer behaviour will also change (Kliestikova et al., 2019). In this respect, age, gender, as well as variables that are more socio-economic in nature like as education, economic status and income are generally monitored. Psychographic segmentation criteria divide consumers into different clusters based on different lifestyles (Kotler and Armstrong, 2004). Lifestyle as one of the characteristics of market behaviour can be tracked and analysed from many different viewpoints, often in combination with other segmentation factors. For purpose of the research we used lifestyle generational market segmentation (Michman et al., 2003). Understanding generation values and motivations has become essential because each generations is driven by unique ideas about the lifestyle to which it aspires (Smith and Clurman, 1997). Each generation represents a different set of unique expectations, experiences, generational history, lifestyles, values, and demographics that influence their buying behaviours. There are many studies, which identify and analyse differences in consumer behaviour according to the customer generations (McCrindle and Wolfiger, 2010, Schewe 
and Meredith, 2004, Bourcier-Bequaert and Barnier, 2010, Rentz and Reynolds, 1991, Reeves and Oh, 2008, Noble and Schewe, 2003, Sima, 2016, DeAlmeida et al, 2016, Chakraborty, 2017, Diaz-Samiento et al., 2017, Nadanyiova, 2018). For the purposes of this contribution, respondents are segmented into five classifications by their generational cohort: (The Baby Boomers; Silent Generation; Generation X; Generation Y and Generation Z.

For this reason, we investigated whether there were customer segments (based on demographic or psychographic factors) in the hotel industry preferring new forms of online marketing communications (banner advertising, online communities, hotel website, online booking systems, email marketing, SEO marketing, SEM marketing, podcasting, Wiki, Facebook, Twitter, Instagram, LinkedIn, YouTube, Blogs, Foursquare geolocation, crowdsourcing, augmented reality, PPC marketing, affiliate marketing, advergaming, copywriting, e-WOM marketing). Respondents were asked to choose the internet communication tool with the hotel they consider most advantageous.

To confirm the existence of such segments, we have established hypotheses:

- Hypothesis E: There is no statistical dependence between gender and some form of online marketing communications.

- Hypothesis F: There is no statistical dependence between education and some form of online marketing communication.

- Hypothesis G: There is no statistical dependence between economic status and some form of online marketing communication.

- Hypothesis $\mathrm{H}$ : There is no statistical dependence between income and some form of online marketing communication.

- Hypothesis I: There is no statistical dependence between the generation and some form of online marketing communication.

The variables examined are of nominal and ordinal character, therefore Kendall tau $\mathrm{C}$ and Kruskall wallis test were chosen as suitable measures of associations (Rimarčík, 2008).

As 730 respondents participated in the marketing survey, the minimum sample size requirement (384 respondents, at 95\% confidence level and 5\% confidence interval) was met and respondents' answers to individual questions asked during the survey period based on determined reliability coefficients with acceptable error estimates can be considered as relevant. For the purposes of the research we chose the questionnaire method via e-mail communication. The questionnaire consisted of three sections, where the first section concerned finding out whether respondents had visited a hotel in the Slovak Republic in the last 12 months. In this way, we only received answers from customers who visited the hotel. The second section of the questionnaire concerned finding out the importance of the Internet for the respondent, the frequency of its use, its benefits and the level of use of internet communication and its tools in communication with the hotel. The last section of the questionnaire focused on the general profile of the respondent, i.e. gender, type of generation, highest level of education, economic status and net income. 
By means of scientific research methods such as excerpting, description, comparative analysis, deduction and induction, determination of absolute and relative number, level of mean values, confirmation of the existence of dependency between variables, we extracted the obtained data from marketing research into the required information necessary to fulfill our goal.

\section{Results}

Figure 1 shows the testing of all customer-oriented statistical hypotheses using statistical one tailed test statistical one tailed test.

Figure 1: Testing of customer-oriented statistical hypotheses

$\begin{array}{cccccc}\text { Hypothesis } & \begin{array}{c}\text { Level of } \\ \text { significance }\end{array} & \begin{array}{c}\text { Test } \\ \text { statistics } \\ \text { (T-value) }\end{array} & \begin{array}{c}\text { Critical } \\ \text { value of } \\ \text { Z-score }\end{array} & \text { Decision rule } & \begin{array}{c}\text { Result of } \\ \text { testing }\end{array}\end{array}$

Ho: $80 \%$ of customers in the Slovak Republic are satisfied with communication with the hotel via the Internet.

H1: More than $80 \%$ of customers in the Slovak Republic are satisfied with communication with the hotel via the Internet.

\begin{tabular}{|l|c|c|c|c|c|} 
Hypothesis A & 0.05 & 8,68037 & 1,64485 & $\mathbf{8 , 6 8 0 3 7}>1,64485$ & Ho rejection
\end{tabular}

Ho: $80 \%$ of customers in the Slovak Republic think that marketing communication with the hotel via the Internet is more efficient than traditional communication tools.

H1: More than $80 \%$ of customers in the Slovak Republic think that marketing communication with the hotel via the Internet is more efficient than traditional communication tools.

\begin{tabular}{|l|l|l|l|l|l|} 
Hypothesis B & 0.05 & $\mathbf{6 , 8 7 1 9 6}$ & $\mathbf{1 , 6 4 4 8 5}$ & $\mathbf{6 , 8 7 1 9 6}>1,64485$ & Ho rejection \\
\hline
\end{tabular}

$H_{0}: 80 \%$ of customers in the Slovak Republic agree that the new forms of online marketing communication used by hotels have an impact on their decision to choose this hotel.

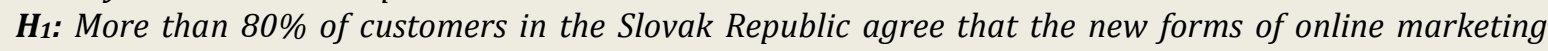
communication used by hotels have an impact on their decision to choose this hotel.

\begin{tabular}{|l|l|l|l|l|l|}
\hline Hypothesis C & 0.05 & $\mathbf{8 , 0 7 7 5 7}$ & $\mathbf{1 , 6 4 4 8 5}$ & $\mathbf{8 , 0 7 7 5 7}>1,64485$ & Ho rejection
\end{tabular}

$H_{0}: 80 \%$ of customers in the Slovak Republic consider a hotel that provides its information through the new forms of online marketing communication used to be of higher quality.

$\mathrm{H}_{1}$ : More than $80 \%$ of customers in the Slovak Republic consider a hotel that provides its information through the new forms of online marketing communication used to be of higher quality.

\section{\begin{tabular}{|l|l|l|l|l|l|} 
Hypothesis D & 0.05 & 4,58131 & 1,64485 & $4,58131>1,64485$ & Ho rejection
\end{tabular}}

Ho: $80 \%$ of customers in the Slovak Republic consider a hotel that provides its information through the new forms of online marketing communication used to be of higher quality.

H1: More than $80 \%$ of customers in the Slovak Republic consider a hotel that provides its information through the new forms of online marketing communication used to be of higher quality.

Source: Authors.

Since the table shows that we have rejected the null hypothesis in all cases, when answering the research question, we can state that the selected new forms of online marketing communication used by the hotel have an impact on the customer's choice of the hotel. To determine the existence of segments preferring certain new forms of marketing communication, all established statistical hypotheses were tested, the results are shown in Figure 2. 
Figure 2: Testing of hypotheses in consideration of the existence of relationships

\begin{tabular}{|c|c|c|c|c|}
\hline Hypothesis & $\begin{array}{c}\text { Level of } \\
\text { significance }\end{array}$ & $\begin{array}{c}\text { Test statistics } \\
\text { (p-value) }\end{array}$ & Decision rule & Result of testing \\
\hline
\end{tabular}

Ho: There is no statistical dependence between gender and some form of online marketing communications.

$\boldsymbol{H}_{1}$ : There is statistical dependence between gender and some form of online marketing communications.

\begin{tabular}{|c|c|c|c|c|}
\hline Hypothesis E & 0.05 & 0.1798 & $0.05<0.1798$ & $\mathrm{H}_{0}$ acceptation \\
\hline
\end{tabular}

Ho: There is no statistical dependence between education and some form of online marketing communication.

H1: There is statistical dependence between education and some form of online marketing communication.

\begin{tabular}{|c|c|c|c|c|} 
Hypothesis F & 0.05 & 0.2669 & $0.05<0.2669$ & $H_{0}$ acceptation \\
\hline
\end{tabular}

Ho: There is no statistical dependence between economic status and some form of online marketing communication.

$\boldsymbol{H}_{1}$ : There is statistical dependence between economic status and some form of online marketing communication.

\begin{tabular}{|l|l|l|l|l|} 
Hypothesis G & 0.05 & $\mathbf{0 . 0 7 3 1}$ & $\mathbf{0 . 0 5}<\mathbf{0 . 0 7 3 1}$ & Ho acceptation
\end{tabular}

$H_{0}$ : There is no statistical dependence between income and some form of online marketing communication. $\boldsymbol{H}_{1}$ : There is statistical dependence between income and some form of online marketing communication.

\begin{tabular}{|l|c|c|c|c|} 
Hypothesis H & 0.05 & 0.3426 & $0.05<0.3426$ & Ho acceptation
\end{tabular}

Ho: There is no statistical dependence between the generation and some form of online marketing communication.

H1: There is statistical dependence between the generation and some form of online marketing communication.

\begin{tabular}{|l|l|l|l|l|} 
Hypothesis I & 0.05 & 0.0000 & $0.05>0.0000$ & Ho rejection \\
\hline
\end{tabular}

Source: Authors.

Since the table shows that we have accepted the null hypothesis in all cases, instead of the hypothesis I. So we can assume that there is a statistically dependence between surveyed variables (generation and forms of online marketing communications). These variables are of ordinal and nominal character, so the appropriate test was Kruskall wallis test of independence. The value measure of associations was 0.377 , which indicates moderate dependence. So we can clearly claim that segmentation of hotel guests in the Slovak republic according the generation cohort is justified, so it is necessary to propose customer segmentation just only on psychographic aspects as a determinant of customer targeting in the online environment.

\section{Discussion}

From the above-mentioned analysis of customers (hotel guests) carried out from marketing research focused on them, content of communication message according to Maráková (2016), types of online communication channels according to Gúčik (2011) and secondary research of characteristic of generation cohorts (McCrindle and Wolfiger, 2010, Schewe and Meredith, 2004, Bourcier-Bequaert and Barnier, 2010, Rentz and Reynolds, 1991, Reeves and Oh, 2008, Noble and Schewe, 2003, Sima, 2016, DeAlmeida et al, 2016, Chakraborty, 2017, Diaz-Samiento et al., 2017) we categorized customers (hotel guests) into five groups, see Figure 3. 
Figure 3: The categories of hotel guest according the influence of new form of online marketing communication

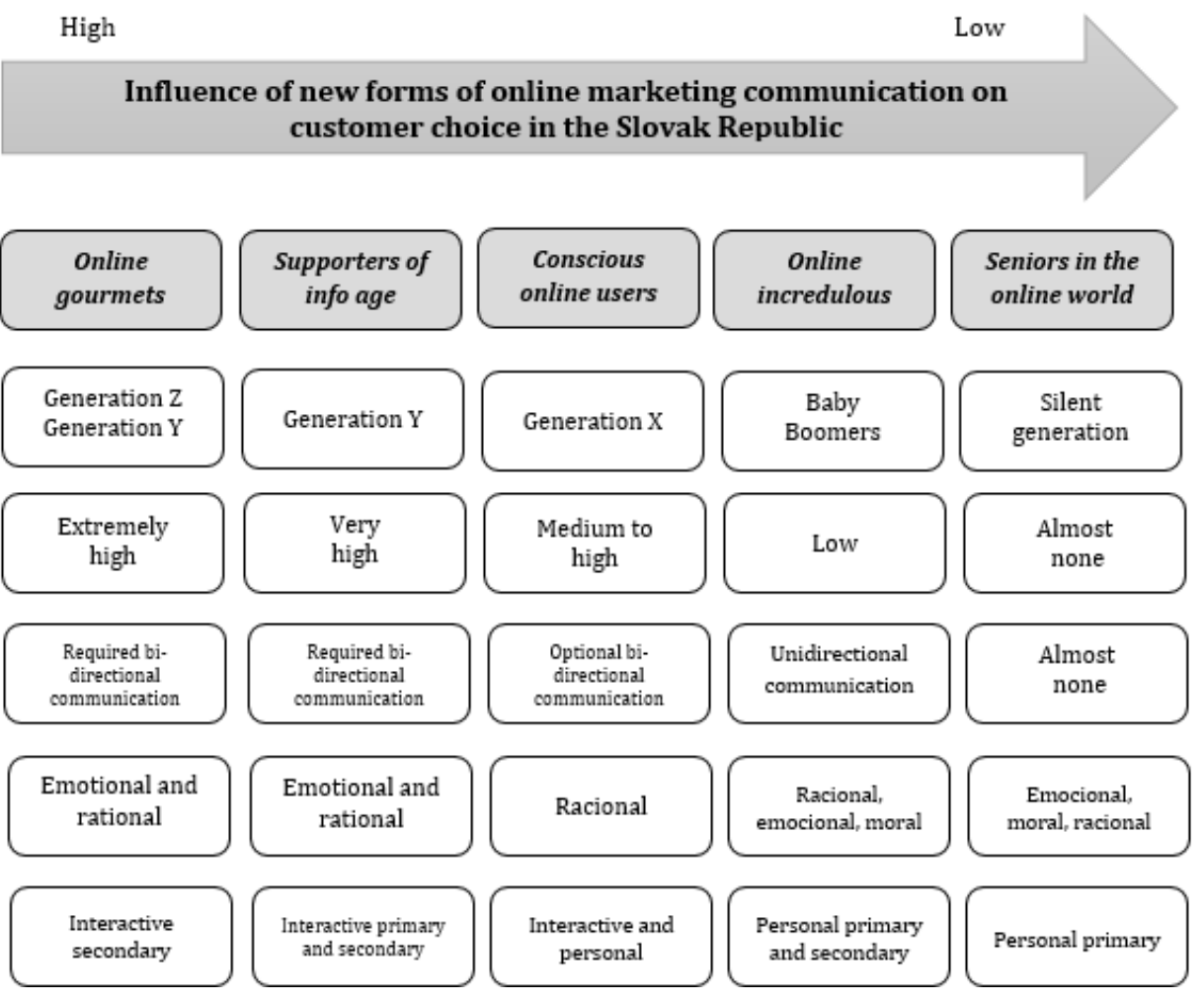

Source: Authors.

Based on the categorization, the hotel should select the appropriate content of the communication message, online communication channels and tools for each customer segment, and it is also necessary for the hotel to identify which customer segments want just only to be informed and which want to participate in the communication as well. 


\section{Online gourmets}

Pic. 1.

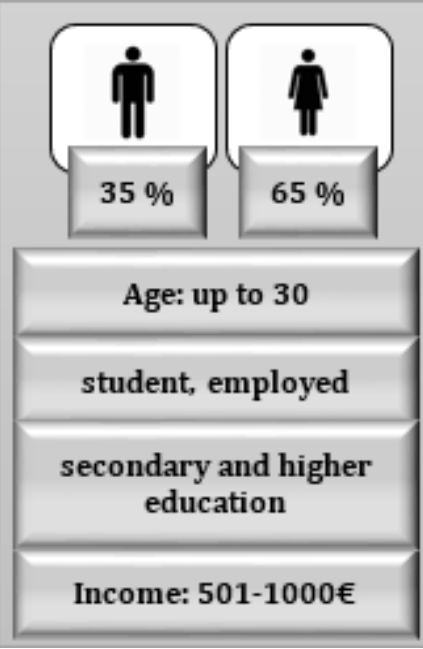

Source: Authors

The online gourmet segment is made up of customers of the generation $Y$ and mainly the generation $\mathrm{Z}$, who are very technically and communication proficient and us modern technologies on a daily basis (Sladek and Grabinger, Ng and McGinnis, 2015). This group of customers is characterized by an exceptionally high degree of information urgency, as well as a degree of engagement in communicating with the hotel in an online environment through new communication tools. This is the type of customers actively seeking information about hotel services. As for the issue, online gourmets have an affective but also rational relationship to it, so the hotel should use a combination of emotional and rational approach to informing them. Since they are customers with their opinions and a high level of interest in information about hotel services, we recommend using two-way communication, which allows for dialogue between the hotel and its customers. For this reason, we also recommend the use of interactive secondary online communication channels with the possibility of open discussion. Media and information are an integral part of their lives and are therefore they are always online. Most of the day they spend on social networks, preferably on Facebook and Instagram, where they by comments, hashtags, likes and shares reflect about the activities of hotels, the quality of their services, the way of communication or the brand of the hotel itself (Cowan, 2014, Fromm and Read, 2018, Pate and Adams, 2013). They also consider online advertising on these social networks more attractive. Since the segment is not concerned about the misuse of its personal data, it is not hampered by behaviourally targeted online banner advertising, which even if it is in line with its interests, even clicks on it. Various websites offering different reviews or geolocation services or online reservation systems can also be an important source of information. Thanks to their skills and education, the online gourmet segment is highly motivated to progress in both professional and private life. Their enthusiasm for life expands with their outlook on travel with recognition (Seemiller and Grace, 2019, Twenge et al. 2010). That is why they are looking for luxury hotels of the **** 
and ${ }^{* * * * *}$ class, congress, wellness, mountain and boutique hotel categories, where they enjoy their holidays with full sip and share all experiences with others through social media. From the point of view of traveling, they are mainly interested in working and educational activities, entertainment, relaxation, getting to know new places, adventure and tourism (Sima, 2016). They are an interesting segment for the hotel as they are perspective people up to the age of 30 , single, educated, employed and interested in rising in the social ladder.

\section{Supporters of info age}

Pic. 2

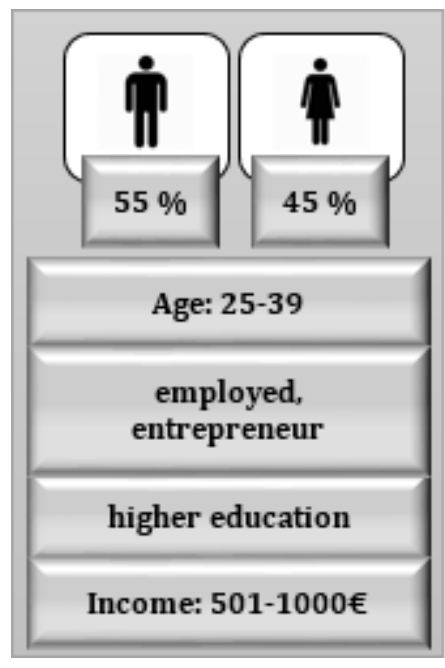

Source: Authors

The second group of customers (hotel guests) is made up of Y-generation customers who are also technically and communicatively proficient, but did not completely succumb to the online environment (Mangold and Smith, 2012). Generation Y associates the best experiences of life with some purchased experience, such as an exotic journey, a concert visit, and so on. Part of these experiences is the social dimension. People are not alone, feel connected to others, or make new friends (Ng and McGinnis, 2015, Fromm, and Garton, 2013, Sima 2016)). Like customers in the first group, these customers are characterized by a high degree of information urgency and a degree of engagement in communicating with the hotel in an online environment through new communication tools. This segment of customers is also actively searching for information about hotel services through selected new forms of online marketing communication with the likelihood of a positive response to the emotional and rational approach of the hotel. Also in this segment we recommend to use two-way communication with the possibility of expressing the customer's specific opinion on the services provided by the hotel. Therefore, we also recommend the use of interactive secondary online communication channels with the possibility of open discussion, i. e. social networks (Facebook, Instagram, YouTube), PPC advertising, behaviourally targeted online banner advertising, 
geolocation services, websites including online reservation systems, email, content marketing and blogs. Although the analysed segment of customers capitalizes their skills through computing and the Internet is their source of information, they do not spend most of the day on the Internet. For them, social media means a way of communicating with their friends, family and acquaintances, including communicating with hotels and brands. This segment is unique in nature, as it differentiates itself from others through its creativity, ideas, authority rejection, travel and shopping. Despite this, customers in this segment are not impulsive as they get to know people, places and things to get exactly what they are looking for. From the point of view of travel, they prefer tourism and adventure activities, work and education activities, entertainment, relax, festivals or accommodation activities (Klapilová Krbová, 2016, Pinzaru et al., 2013, Pate and Adams, 2013, Mangold, 2012). Therefore, they like to stay in cheaper classes of hotels ( ${ }^{* * *}$ ), but do not despise even luxury hotels $\left({ }^{* * * *},{ }^{* * * *}\right)$. Within the hotel category they are interested in holiday, mountain, wellness and congress hotels. From the point of view of using new forms of online marketing communication, they are also a very interesting segment for the hotel, as they are perspective people aged 25 to 39 years, single, but also family based, educated, employed and interested in rising in the social ladder. 


\section{Conscious online users}

Pic.3

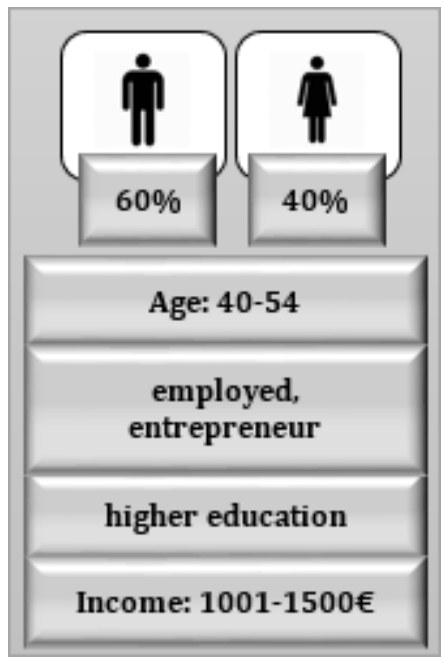

Source: Authors

The third segment of customers consists of so-called the conscious online users of Generation X. Representatives of the Generation have the huge advantage of being one of the first to meet computers and current technology, so for this age category it is easy to adapt to the new technology industry (Dabija et al., 2018). Generation X has many ambitions and can adapt quickly. The typical characteristics of the representatives of this generation include independence and self-sufficiency (Hensler, 2013). The degree of urgency for information about hotel products and services is moderate compared to previous segments. While the segment's involvement in the hotel communication process through new forms of online marketing communications is bidirectional, it is based on a voluntary basis, implying that customers pay more attention to convenience (DeAlmeida et al., 2016). The lack of initiative seeking information about hotel products and services, coupled with low customer effort and convenience, causes this segment to take into account only essential information based on figures and facts in its hotel selection decisions. For this reason, we recommend that hotels have to use a rational approach when creating the content of a communication message within this segment. Conscious online users prefer to receive information through both online interactive and personal channels, i. j. we recommend the hotel website, blogs, copywriting (content marketing) as they tend to believe in customer feedback about hotel services, discussions and reviews. Social networks need to be used to a lesser extent, since the communication of these customers is more clunky and consists only of communication with family, friends and acquaintances (Dabija et al., 2018). These customers also prefer to obtain information from hotel staff or their own experience. The conscious online users segment is stabilized in its life with a more or less fixed status. The shopping and travel an important part of their lifestyle. They like traveling for culture, exploring new places, hiking, entertainment, relaxing, educational and working activities (Sima, 2016, McRindle and Wolfinger, 2010, Twenge et al, 2010). Accommodation is more simple, rather hotels of ${ }^{* * *}$ and ${ }^{* * * *}$ class and categories like as mountain recreational, wellness, spa and congress hotel. 


\section{Online incredulous customers}

Pic.3

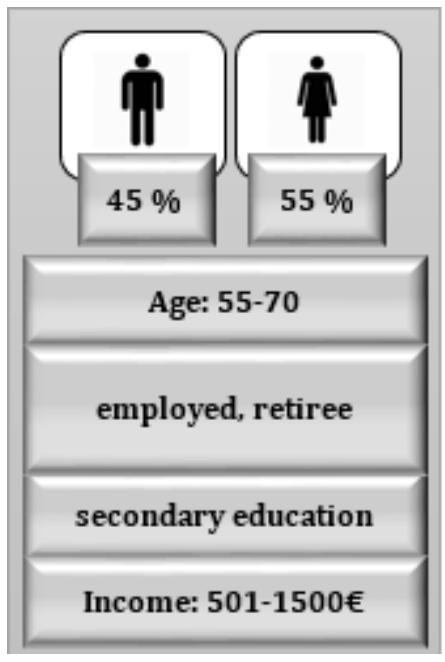

Source: Authors

The penultimate customer segment consists of customers of the Baby Boomers generation. Baby Boomers pay their children education, clothing, pocket money, they buy them apartments, caravans, new cars. After the birth of grandchildren, they save money for another gifts and dedicate their next life to the care of grandchildren. Many, however, live fully, pursue their hobbies, travel, educate (Patterson and Pegg, 2009, Pavlic et al., 2018). They are less proficient in technical, communication technologies and Internet use, but still have an interest and desire to continue their education at least to the extent that they are able to use these technologies very easily. Rather, they are mistrustful of new forms of online marketing communications, taking into account the opinions of their closest friends and acquaintances (Tiago et al., 2016, Chakraborty, 2017). This segment's interest in information gained through new online forms of marketing communication used by the hotel is superficial, consisting of a low degree of urgency for this information. Therefore, the desired level of engagement is only one-way communication for even greater convenience than in the previous segment. The need for communication in its new online forms is limited. Therefore, we recommend that the hotel have to focus primarily on personal communication channels primarily consisting of providing information directly at the place of delivery of the hotel product, respectively services. The communication should be so imaginative that it can reach the customer segment. In addition, we also recommend the use of secondary personal communication channels providing information mainly via email or blogs as part of content marketing. This implies that when providing information, the hotel should apply a combination of rational, emotional and moral style when creating the content of the communication message. This segment likes to travel for culture, relaxation, exploring new places, undemanding tourism and natural beauties (Diaz-Samiento et al., 2017, Sima, 2016, Noble and Schewe, 2003). They prefer hotels of ${ }^{* * *}$ to ${ }^{* * * * *}$ class and from categories mainly spa, recreational and wellness hotels. 


\section{Seniors in the online world}

Pic. 4

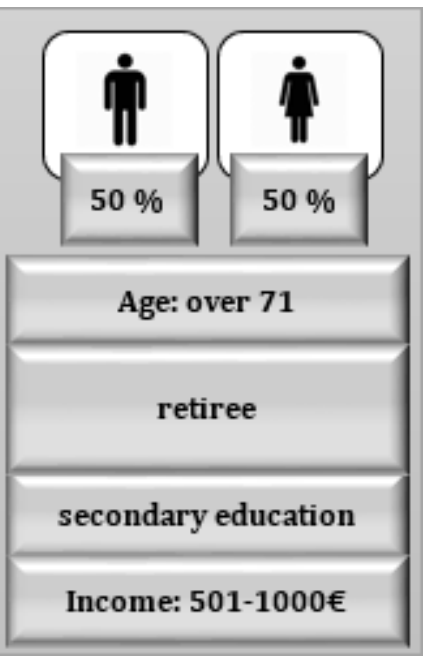

Source: Authors

The last group of customers is made up of representatives of the silent generation. These people focused on the career they preferred to activism. They grew up at a time when it was not safe to express their views and attitudes (Joesalu, 2016). In terms of the use of communication technologies in the online environment, they use them mainly to stay in touch with their family and loved ones (Randal et al., 2015). It is very difficult to accept new things, especially things and forms of communication in the online environment (Henger and Henger, 2012). Therefore, the degree of urgency of information and the degree of involvement, especially in the field of new forms of online marketing communications, are almost no ones. The only way the hotel should communicate with this customer segment is through primary personal communication channels presenting numbers, facts and moral-emotional attitude. An adequate means of communication could be to present information directly at the point of sale of a hotel product or service and, to a minimum, communicate by email or blogging. The seniors in the online world are a segment that is more or less retired and has more free time. Such people like to know new places and things, they like to relax and go for culture (Henger and Henger, 2012, Sima, 2016). When staying, they prefer spa and holiday hotels of *** to **** class.

\section{Conclusion}

The current market offers a very wide range of products that are linked to even more content. Therefore, it is necessary from the position of the company to provide clear and purposeful information to its customers through appropriately selected and interconnected communication tools. From the customer's point of view, there is still a strong emphasis on their own experience, which they can spread and share very quickly and easily in today's electronic and mobile communications. It is therefore necessary to focus on new forms of online communication. However, the success of communication depends not only on broadcasting information, but also on the definition of target groups 
of customers. The determination of customers helps the hotel better plan adequate online communication, i.e. the hotel needs to create heterogeneous communication messages for heterogeneous groups and use adequate online communication channels or methods for each identified group. Therefore, the aim of this contribution was to propose the customer segmentation based on psychographic and demographic aspects as a determinant of customer targeting in the online environment. Time and geographical constraints can be considered as the main limits of work. This restriction was especially reflected in the selection of respondents, when only Slovak hotel customers were elected. This limitation can be removed if the research is considered to be relevant for the solution and the results achieved are subject to subsequent verification in an international environment. If these barriers were removed, more accurate results could be achieved. Another limit is that the found segments change over time. As consumers evolve and change as a result of time and life events, segments are also changing (their characteristics and size). It is therefore necessary to continuously check whether the segments maintain their profile and whether the marketing orientation still reaches the target group.

\section{Acknowledgement}

This paper is an output of scientific project VEGA no. 1/0718/18: The impact of psychographic aspects of pricing on the marketing strategy of companies across products and markets.

\section{References}

BOURCIER-BEQUAERT, B. and BARNIER, V., 2010. Toward a Larger Framework of the Generation Concept in Marketing. Recherche et Applications en Marketing. 25(3), 115-134, ISSN 2051-5707.

BRETTEL, H. J. and SPILLER-ATTIG, M. J., 2013. Price and advertising effectiveness over the business cycle. Journal of Marketing Research. 50(2), 177-193, ISSN 0022-2437.

CHAKRABORTY, T. and BALAKRISHNAN, J., 2017. Exploratory tendencies in consumer behaviour in online buying across gen $\mathrm{X}$, gen $\mathrm{Y}$ and baby boomers. International journal of value chain. 8(2), 135-150, ISSN 1741-5357.

CHIJIOKE, N., VU, H.M. and OLATUNJI, F., 2018. Influence of strategy formulation drivers on strategic performance. Ekonomicko-manazerske spektrum. 12(2), 15-25, ISSN 1337 0839.

CLOW, E. and BAACK, D., 2008. Reklama, propagace a marketingová komunikace. Brno: Computer Press. ISBN 978-80-251-1769-9.

COWAN, M., 2014. Generation Z: The new kids on the block have arrived. [online]. London: Happen Group Ltd. [accessed: 2019-07-03]. Available at: https://gettinggenz.files.wordpress.com/2014/07/happen genz new kids.pdf. 
DABIJA, D. C., BEJAN, B. A. M., TIPI, N., 2018. Generation X versus millenials communication behaviour on social media when purchasing food versus tourists services. E \& M Ekonomie a management. 21(1), 191-205, ISSN 1212-3609.

DeALMEIDA, G. T., ITUASSU, C. T., MOURA, L. R. C., 2016. The meaning of consumption for members of generations X, Y and Z. Revista ciencias administrativas. 22(2), 605-636, ISSN 1414-0896.

DIAZ-SAMIENTO, C., LOPEZ-LAMBRANO, M., RONCALLO-LAFONT, L., 2017. Understanding generations: a review of the concept, classification and distinctives traits among baby boomers, generation X and millennials. Clio america. 11(22), 188-204, ISSN 1909-941X.

FROMM, J. and READ, A., 2018. Marketing to Gen Z: The Rules for Reaching This Vast--and Very Different generation of influencers. AMACOM American Management Association. ISBN 978-0814439272.

FROMM, J. and GARTON, C., 2013. Marketing to Millennials: Reach the Largest and Most Influential Generation of Consumers Ever. New York: AMACOM, American Management Association. ISBN 978-0814433225.

HENGER, B. and HENGER, J., 2012. The Silent Generation: 1925-1945. Bloomington: Autor House. ISBN 978-1477204719.

HENSLER, C., 2013. Generation X Goes Global: Mapping a Youth Culture in Motion. Routlege. ISBN 978-0415699440.

GÚČIK, M., 2011. Marketing cestovného ruchu. Banská Bystrica: Dali BB, s. r. o. ISBN 97880-89090-85-3.

JAKOVIC, B. and GALETIC, F., 2014. Marketing and commercial activities offered on Croatian five-star hotel web sites. Procedia Engineering. 69, 112-120. ISSN 1877-7058.

JÄRVINEN, J., TOLLINEN A., KARJALUOTO, H. and JAYAWARDHENA, C., 2012. Digital and social media marketing usage in B2B industrial section. Marketing Management Journal. 22(2), 102-117. ISSN 2333-6099.

JOESALU, K., 2016. We were the children of a romantic era: nostalgia and the nonideological everyday through the perspective of a Silent Generation. Journal of baltic studies. 47(4), 557-577, ISSN 0162-9778.

KLAPILOVÁ KRBOVÁ P., 2016. Shopping Behaviour of Generation Y: A Comparison of Czech Republic and Slovakia. Acta Universitatis Agriculturae Et Silviculturae Mendelianae Brunensis. 64(2), 617-626, ISSN 1211-8516.

KLIESTIKOVA, J., DURANA, P. and KOVACOVA, M., 2019. Naked consumer's mind under branded dress: Case study of Slovak Republic. Central European Business Review. 8(1), 15 32, ISSN 1805-4862.

KOTLER, P., 2007. Moderní marketing. Praha: Grada Publishing. ISBN 978-80-247-15452. 
KOTLER, P. and ARMSTRONG, G., 2004. Marketing. Praha: Grada Publishing. ISBN 8024705133.

KRAMÁROVÁ, K., 2009. Integrovaná marketingová komunikácia a model hodnotového spektra. Logistický monitor. 34-38. ISSN 1338-5651.

KRYLOV, S., 2019. Strategic customer analysis based on balanced scorecard. Ekonomickomanazerske spektrum. 13(1), 12-25, ISSN 1337-0839.

MANGOLD, W. and SMITH, K., 2012. Selling to Millennials with online reviews. Business Horizons. 55(2), 141-153, ISSN: 0007-6813.

MARÁKOVÁ, V., 2016. Marketingová komunikácie v cestovnom ruchu. Bratislava: Wolters Kluwer. ISBN 978-80-8168-394-7.

McCRINDLE, M. and WOLFINGER, E., 2010. The ABC of XYZ: Understanding the Global Generations. University of New South Wales Press. ISBN 978-0-9924839-0-6.

NADANYIOVA, M., 2018. The brand building through viral marketing on social networks and its perception by different consumers' generations. In: 15th Annual International Scientific Conference on Marketing Identity - Digital Mirrors Location. Trnava: Univ Ss Cyril \& Methodius Trnava, Fac Mass Media Commun; Fac Mass Media Commun. 441-450.

MICHMAN, R. D., MAZZE, E. M. and GRECO, A. J., 2003., Lifestyle Marketing: Reaching the New American Consumer. Westport: Praeger. ISBN 978-0313361562.

NG, E. S. W. and McGINNIS J.J., 2015. Millennials: who are they, how are they different, and why whould we care?. In: BURKE, R., COOPER, C. and ANTONIOU A., The Multigenerational and Aging Workforce. Edward Elgar Pub, 121-137, ISBN 978-1783476572.

NOBLE, S. M. and SCHEWE, C. D., 2003. Cohort segmentation: An exploration of its validity. Journal of business research, 56(12), 979-987, ISSN 0148-2963.

PATE, S. and ADAMS, M., 2013. The Influence of Social Networking Sites on Buying Behaviors of Millennials. Atlantic Marketing Journal. 2(1), 92-109, ISSN 2165-3879.

PATTERSON, I. and PEGG, S., 2009. Marketing the Leisure Experience to Baby Boomers and Older Tourists. Journal of hospitality marketing and management. 18(2-3), 254-272, ISSN 1936-8623.

PAVLIC, I. VOJVODIC, K. and PUH, B., 2018. Segmenting the baby boomer generation: an example of croatian consumers. Ekonomski vjesnik. 31(1), 47-63, ISSN 0353-359X.

PINZARU, F., SAVULESCU, R. and MITAN, A., 2013. New practices in marketing to Generation Y. product placement in Romanian pop music videos. International Journal of Academic Research. 5, 320-326, ISSN 2348-7666.

PIZANO, V., 2012. Typológia slovenských internetových užívatel'ov podl'a vnímania nových foriem marketingovej komunikácie. Trnava. Dissertation Thesis Universitas Tyrnaviensis, FMK. 
QUEIROZ, A. F., LIMA-FILHO, D. O. and FINOCCHIO, C. S., 2019. Consumer life style of organic vegetables: a comparison between VALS-2 and AIO. Caderno profissional de marketing unimep. 7(1), 118-133, ISSN 2317-6466.

RANDALL, N. H., PAULEY, S. C. and AARON, B., 2015. Family social networks, reciprocal socialization and the adoption of social media by baby boomer and silent generatin women. In: ROBINSON, L., COTTEN, S. R. and SCHULZ, J., Communication and information technologies annual: politics, participation, and production. Emerald Group Publishing Limited, 135-160, ISBN 978-1784414542.

REEVES, T. C. and OH, E., 2008. Generation Differences. In: SPECTOR, J. M., MERRILL, D., van MERRIENBOER, J., and DRISCOLLE, M., Handbook of research on educational communications and technology. Taylor \& Francis Group, 295-303. ISBN 9780805858495.

RENTZ, J. O. and REYNOLDS, F. D., 1991. Forecasting the effects of an aging pouplation on product consumption - an age-period-cohort framework. Journal of marketing research. 28(3), 355-360, ISSN 0022-2437.

RIMARČÍK, M., 2007. Štatistika pre prax. ISBN 978-80-969813-1-1.

SCHEWE, C. D. and MEREDITH, G., 2004. Segmenting global markets by generational cohorts: Determining motivations by age. Journal of Consumer Behaviour. 4(1), 51-63, ISSN 1472-0817.

SEEMILLER, C. and GRACE, M., 2019. Generation Z: A Century in the Making. New York: Routledge. ISBN 978-1-138-33731-2.

SLADEK, S. and GRABINGER, A., Gen Z: The first generation of 21 st Century has arrived!. online]. XYZ University [accessed: 2019-10-03]. Available at: https://www.xyzuniversity.com/wp-content/uploads/2018/08/GenZ_Final-dl1.pdf.

SIMA, C., 2016. Generations BB, X, Y, Z, alpha - the changing consumer in the hospitality industry. In: IVANOVA M., IVANOV, S. and MAGNINI, V. P., Routledge handbook of hotel chain management. Routledge, 471-479. ISBN 9781138805057.

SMITH, J. W. and CLURMAN, A. S., 1997. Rocking the Ages: The Yankelovich Report on Generational Marketing. HarperCollins e-books.

TIAGO, M. B., PINHEIRO, M. T., COUTO, J. P. D., TIAGO, F.G.B., FARIA, S.M.C.D., 2016. Baby boomers turning grey: European profiles. Tourism management. 54, 13-22, ISSN 02615177.

TWENGE, J., CAMPBELL, S., HOFFMAN, B. and Lance, C., 2010. Generational Differences in Work Values: Leisure and Extrinsic Values Increasing, Social and Intrinsic Values Decreasing. Journal Of Management. 36(5), 1117-1142, ISSN 0149-2063.

VALETTEFLORENCE, P. and JOLIBERT, A., 1990. Social values, AIO, and consumption patterns - exploratory findings. Journal of business research. 20(2), 109-122, ISSN 01482963. 


\section{Contact address of the author(s):}

Assoc. prof. Elvira Nica, Ph.D., The Center for Human Resources and Labor Studies at AAER, New York City, NY, USA; The Bucharest University of Economic Studies, Romania, e-mail: popescu_elvira@yahoo.com

Ing. Lubica Gajanova, Ph.D., Department of Economics, The Faculty of Operation and Economics of Transport and Communications, University of Žilina, Univerzitna 1, 010 26, Zilina, Slovakia, e-mail: lubica.gajanova@fpedas.uniza.sk

Ing. Eva Kicova, Ph.D., Department of Economics, The Faculty of Operation and Economics of Transport and Communications, University of Žilina, Univerzitna 1, 010 26, Zilina, Slovakia, e-mail: eva.kicova@fpedas.uniza.sk 